\title{
Love and Marital Quality in Romantic Relationships Mediated and Non-Mediated by Internet ${ }^{1}$
}

\author{
Karla Rafaela Haack ${ }^{2}$ \\ Denise Falcke \\ Universidade do Vale do Rio dos Sinos, São Leopoldo-RS, Brazil
}

\begin{abstract}
Love is one of the most desired feelings by human beings. According to the triangular theory of love, it is composed of three elements: intimacy, passion and decision/commitment, which constitutes a dimension related to the quality of love the partners perceive in their relationship. This study aims to compare the three elements of love and marital quality of 86 Internet users (43 in a relationship mediated by the Internet and 43 with a physical relationship). The results indicate that there is a significant difference in the intimacy, the decision/commitment and the whole dimension of love, as well as in the marital quality between partners who have a relationship mediated by Internet and the ones in a physical relationship. We can conclude that the Internet is a great tool for people to meet, but that it is important for the relationship to develop in a face-to-face context.
\end{abstract}

Keywords: marital relations, Internet, love

\section{O Amor e a Qualidade Conjugal em Relacionamentos Amorosos Mediados e Não Mediados Pela Internet}

\begin{abstract}
Resumo: O amor é um dos sentimentos mais desejados pelo ser humano. De acordo com a teoria triangular do amor, este é composto por três elementos: intimidade, paixão e decisão/compromisso, constituindo-se em uma dimensão relacionada à qualidade percebida pelos cônjuges no seu relacionamento. O objetivo deste estudo quantitativo foi comparar os três elementos do amor e a qualidade conjugal de 86 usuários de Internet divididos em dois grupos (43 em um relacionamento amoroso mediado pela Internet e $43 \mathrm{em}$ um relacionamento presencial). Os resultados revelaram diferença significativa na intimidade, na decisão/compromisso e na dimensão total do amor, bem como na qualidade conjugal, entre os usuários que possuem um relacionamento mediado pela Internet e os usuários em relacionamentos presenciais. Conclui-se que a Internet é uma excelente ferramenta para que pessoas se conheçam, porém é importante que o relacionamento se desenvolva em um contexto presencial.
\end{abstract}

Palavras-chave: relações conjugais, Internet (rede de computador), amor

\section{Amor y la Calidad del Matrimonio en las Relaciones Amorosas Mediadas y No Mediadas por Internet}

\begin{abstract}
Resumen: El amor es uno de los sentimientos más deseados por los seres humanos. La teoría triangular del amor cree que está compuesto por tres componentes: intimidad, pasión y decisión/compromiso, dimensiones relacionadas con la percepción de los cónyuges a cerca de la calidad de su relacionamiento. La finalidad de este estudio cuantitativo fue comparar los tres elementos del amor y de la calidad marital en 86 usuarios de Internet divididos en dos grupos (43 en una relación de amor mediada por la Internet y 43 en un relacionamiento presencial). Los datos mostraron diferencias significativas en la intimidad, en la dimensión decisión/compromiso y en la dimensión total del amor, así como en la calidad del matrimonio entre los usuarios que tienen una relación mediada por la Internet y los usuarios en las relaciones presenciales. Llegamos a la conclusión de que Internet es una excelente herramienta para que las personas se encuentran, pero es importante que la relación se desarrolle en un contexto presencial.
\end{abstract}

Palabras clave: relaciones conyugales, Internet, amor

Over time, love has been one of the most wanted and desired feelings in human behavior (Oltramari, 2009). While classical authors believe that it is a universal feeling (Freud, 1969; Schopenhauer, 1970), love can also be understood as a social construction, with distinctive marks according to the role culture plays (Beall \& Sternberg, 1995; Neves, 2003).

\footnotetext{
1 Paper deriving from the master's thesis of the primary author, under the advice of the secondary author and defended in the Graduate Program in Clinical Psychology at Universidade do Vale do Rio dos Sinos in 2012.

Support: Coordination for the Improvement of Higher Education Personnel (CAPES).

${ }^{2}$ Karla Rafaela Haack. Av. Unisinos, 950 (Sala 2A109). Jardim Itu Sabará. CEP 93022-000. São Leopoldo-RS, Brazil. E-mail: krh.psi@gmail.com
}

According to Naar (2013), at some moment, love involves the desire for the other person's wellbeing and/or an evaluation, as people commonly justify their love by citing their partners' characteristics. The author also mentions that loving involves a feeling of emotion, characterizing a mental condition. Thus, the definition of what love is varies over time, the historical period experienced and the existing cultural particularities. Understanding what love is is extremely relevant, as its definition gives meaning to what is appropriate and desirable in human relations (Mônego \& Teodoro, 2011; Sternberg, 1998).

In the attempts to help and understand this feeling, Sternberg (1989) created the Triangular Theory of Love, which is one of the most complete studies about the 
phenomenon. The theory describes that this feeling consists of three elements, which constitute the three sides of a triangle: intimacy, passion and decision/commitment.

With regard to intimacy, Sternberg describes the feelings involved in the experience of comfort, happiness and communication in the relationship, producing a bond in the couple, promoting proximity and connection in the relationship (Cassepp-Borges \& Pasquali, 2012; Gao, 2001; Hernandez \& Oliveira, 2003). Thus, intimacy consists of the following elements: the desire to promote the other person's wellbeing; the happiness to share life experiences; mutual respect; the possibility to be present at the necessary moments in the partner's life; the understanding to share life and material goods with the other person; granting and receiving emotional support; communication and acknowledgement of the partner's value.

Passion refers to what rules romance: physical attraction and the sexual relationship (Gao, 2001; Hernandez \& Oliveira, 2003; Mônego \& Teodoro, 2011). As it expresses desires and needs, passion can generate motivational factors that provoke excitement or other needs, such as self-esteem, dominance, submission and affiliation. Thus, passion could be described as: romantic perceptions; physical desire to be with the partner; mutual sexual satisfaction; physical and emotional excitement (Sternberg, 1989).

As the name suggests, the decision/commitment factor involves two elements: the decision to love the other and the commitment to maintain that love. It is important to highlight that both do not necessarily happen at the same time. Deciding to love does not mean making a commitment, or oppositely, like in arranged marriages, as that is the component that, even without passion and intimacy, maintains the relationship. The decision/commitment factor indicates the willingness to represent or articulate that love; understanding that the relationship goes beyond a transitory whim or investing in the relationship in a certain space and time (Cassepp-Borges \& Pasquali, 2012; Hernandez, 1999; Mônego \& Teodoro, 2011).

The combination of the factors described above reveals the different forms of loving. Liking involves intimacy alone, without passion or commitment, almost a friendship; infatuation only results from passion, which generates psychophysiological reactions, which appear and disappear in a short period; empty love, in which only decision/commitment is present, is evidenced in arranged marriages; companionate love is the sum of the intimacy and commitment components; fatuous (unreal, foolish) love is the combination of passion and commitment; romantic love unites passion and intimacy; and consummate love adds up the three elements of love (Engel, Olson, \& Patrick, 2002).

In his theory, Sternberg (1989) also indicates that, in loving relations, although two individuals are involved, there may be others, which are the persons each partner idealizes. The author states that one of the partners' happiness and satisfaction in a relationship can be significantly affected by a fantasy of perfection or by the expectation based on a person's present and past.
Therefore, in Psychology, many authors attempt to understand the aspects involved in the quality of romantic relationships (Mônego \& Teodoro, 2011; Mosmann, Zordan, \& Wagner, 2011; Silva Neto, Mosmann, \& Lomando, 2009; Wachelke, Andrade, Cruz, Faggiani, \& Natividade, 2004). Although the concept of marital quality is very complex, Mosmann, Wagner and Féres-Carneiro (2006) define it as a dynamic and interactive process of the couple that implies each partner's assessment of the quality of the relationship. The context, the personal resources the couple uses and the adaptive processes are the three main dimensions that induce the partners' self-perception about the quality of the relationship and are influenced by: experiences in the family of origin, educational level, personality characteristics and phase of the lifecycle the couple is in (Mosmann et al., 2006, 2011). Hence, marital quality is a complex phenomenon that is constantly under construction, as it is influenced by many aspects, like the personality characteristics of the people involved, the experiences they bring from their families of origin and the way the couple builds its relationship (Wagner \& Falcke, 2001).

Marital satisfaction is one of the components of the relationship quality. In that sense, Arriaga (2001) and Mosmann et al. (2006) consider that it corresponds to a person's assessment of positive aspects that exist in the relationship. According to Dela Coleta (1989, 2012), satisfaction is a subjective reaction experienced in the relationship, which results from the difference between the perception of reality and what the partners want for the relation (Hendrick, 1981; Sanderson \& Cantor, 1997). It is influenced by conscious and unconscious elements and by factors like gender, level of education, socioeconomic level, religion, personality characteristics, values, attitudes and needs (Arias \& House, 1998; David \& Stafford, 2013; Falcke, Diehl, \& Wagner, 2002; Meltzer, McNulty, Jackson, \& Karney, 2013; Mosmann et al., 2011).

People who are more satisfied with their romantic relationship commonly experience situations in other life contexts (work, group of friends etc.) more positively. Thus, Andrade et al. (2005) affirm that satisfaction in the relationship is an important predictor of psychological wellbeing. Departing from a context in which the relationships occur not only in face-to-face contexts, but considering the increasing number of people who relate through the Internet, the question is raised: Do these data apply to face-to face relations as well as relations mediated by the Internet? Can one consider that romantic relationships developed exclusively through the Internet (without physical presence) have the same quality and love characteristics as face-to-face relationships?

Authors (Lai, Lin, Chen, Gwung, \& Li, 2013) state that, when the Internet is used for social interactions, to watch videos and look for information, it can enhance interpersonal relationships. When it is used to visit pornographic websites and play games, on the other hand, it does not directly affect 
these relationships. Social networks like Facebook have been very popular and have significantly affected the way people build and maintain their interpersonal relationships (Hand, Thomas, Buboltz, Deemer, \& Buyanjargal, 2013).

If, in the past, to fall in love and create affective bonds, a face-to-face meeting was needed, today, these meetings can happen through spaces offered by the Internet, particularly relationship sites and social networks, which allow people located in different contexts and geographic regions to meet and relate (Freire et al., 2010). According to Slouka (1995), the relationships developed in the context of the Internet are more superficial and impersonal, and less gratifying than the relationships not mediated by the Internet (physical relationships). Kraut et al. (1998) agree with the argument, indicating that a high level of Internet use is associated with depression and solitude. On the opposite, Lea and Spears (1995) consider that relationships mediated by the Internet are as gratifying as those not mediated, as the lack of proximity and visual information can be overcome through the organization of online meetings or the exchange of photographs. According to those authors, this type of relationship creates new opportunities for the way in which individuals interact.

Civiletti and Pereira (2002) developed an empirical study to analyze the computer-mediated affective and sexual relationships in chat rooms. In the research, 140 people over 18 years of age participated, mostly living in the states of Rio de Janeiro and São Paulo, although a smaller number of people from other states and even other countries also participated. The study indicated that $37.1 \%$ of the participants sought affective-sexual relationships on the Internet.

Online relationship sites have nourished a billion-dollar industry around the world and represented one of the main markets to grow despite the global economic crisis (Wesley, 2011). In the media, the movie You've got mail (Ephron, 1998) got well known because of its story about a couple that meets through the Internet. In addition, in Brazil, reports describing the profile of relationship website users are common (Cuminale, 2009), telling how to deal with a virtual love (Scherma \& Marques, 2012), presenting histories about relationships that started through the Internet ("I met my love through the Internet", 2008) and explaining how romantic life through the Internet works ("My romantic life on the Internet", 2009).

This reveals a stimulus to develop this kind of relationship. Nevertheless, the question is raised: to what extent does society want to sell the idea that these romantic relationships are satisfactory? Do these relationships actually have the same quality as the relationships not mediated by the Internet?

Departing from these inquiries, the objective in this study was to get to know and compare the levels of marital quality, intimacy, passion and decision/commitment in Internet users with a romantic relationship mediated by the Internet and users with a romantic relationship not mediated by the Internet. In this study, like in an earlier study (Haack \& Boeckel, 2009), the term romantic relationship mediated by the Internet (RRMI) refers to romantic relationships that take place exclusively through the Internet, without any physical contact with the partner. The term romantic relationship not mediated by the Internet, on the other hand, refers to physical romantic relationships (PRR).

\section{Method}

A quantitative study with an exploratory, comparative and correlational design was undertaken. The quantitative method refers to studies that work with numbers and use statistical models to explain the data (Bauer \& Gaskell, 2003).

\section{Participants}

The respondents were 276 Internet users. Participants who declared being married and living together were excluded from the study. In total, 43 were involved in a romantic relationship mediated by the Internet (RRMI). The remainder of the database was paired according to gender. In addition, further approximation was sought between the length of the participants' relationship and their age, considering those with relationships mediated and not mediated by the Internet. Thus, 43 participants were found who were involved in a physical romantic relationship (PRR), totaling 86 participants.

An intentional sampling process was adopted. Also, the "snowball" sampling criterion was considered, as the participants were asked to forward to research invitation by e-mail.

Forty-two men and 44 women participated in the research, with ages ranging between 18 and 55 years $(M=29.5 ; S D=8.1)$, living in 13 Brazilian states (Alagoas, Bahia, Espírito Santo, Goiás, Maranhão, Minas Gerais, Pará, Paraíba, Rio de Janeiro, Rio Grande do Sul, Rondônia, Santa Catarina and São Paulo). Among the 86 research participants, $56.2 \%$ declared they were involved in a relationship and the remainder (43.8\%), despite considering they were involved in a romantic relationship, declared they were single. The mean length of the romantic relationships mediated by the Internet was 8.37 months $(S D=14.27)$, against 11.93 months $(S D=14.39)$ for the physical romantic relationships. The majority did not have children, worked and had finished secondary education, as observed in Table 1.

\section{Instruments}

General information questionnaire. To map the participants, collecting data like age, gender, marital situation, length of romantic relationship, length of Internet use per week, among others.

Golombok Rust Inventory of Marital State (GRIMS). Developed by Rust, Bennun, Crowe and Golombok (1988), the instrument assesses the quality of the marital relationship through aspects that are considered important in a relationship. These are: satisfaction, communication, shared interests, trust and respect. The scale consists of 28 items, 
Table 1

Sociodemographic Characteristics of Research Participants

\begin{tabular}{|c|c|c|c|}
\hline & $\begin{array}{l}\text { Romantic relationship mediated } \\
\text { by Internet }\end{array}$ & $\begin{array}{l}\text { Romantic relationship not } \\
\text { mediated by Internet }\end{array}$ & General \\
\hline \multicolumn{4}{|l|}{ Marital situation } \\
\hline Single & $71.8 \%$ & $17.1 \%$ & $43.8 \%$ \\
\hline With Partner & $28.2 \%$ & $82.9 \%$ & $56.2 \%$ \\
\hline \multicolumn{4}{|l|}{ Children } \\
\hline Yes & $43.6 \%$ & $21.1 \%$ & $32.5 \%$ \\
\hline No & $56.4 \%$ & $78.9 \%$ & $67.5 \%$ \\
\hline \multicolumn{4}{|l|}{ Education } \\
\hline No formal education & $4.8 \%$ & $0 \%$ & $2.4 \%$ \\
\hline Primary & $4.8 \%$ & $0 \%$ & $2.4 \%$ \\
\hline Secondary & $57.1 \%$ & $68.2 \%$ & $60 \%$ \\
\hline Higher & $23.8 \%$ & $25.6 \%$ & $24.7 \%$ \\
\hline Graduate & $9.5 \%$ & $11.6 \%$ & $10.6 \%$ \\
\hline \multicolumn{4}{|l|}{ Employment } \\
\hline Works & $85.0 \%$ & $72.1 \%$ & $78.3 \%$ \\
\hline Does not work & $15.0 \%$ & $27.9 \%$ & $21.7 \%$ \\
\hline Age $(M)$ & $\begin{array}{c}30.81 \\
(18-49 \text { years }) \\
(S D=6.6)\end{array}$ & $\begin{array}{c}28.26 \\
(18-55 \text { years }) \\
(S D=9.3)\end{array}$ & $\begin{array}{c}29.5 \\
(18-55 \text { years }) \\
(S D=8.1)\end{array}$ \\
\hline
\end{tabular}

assessed on a four-point Likert scale (strongly disagree, disagree, agree and strongly agree). The lower the score, the better the marital quality and, the higher the score, the more the relationships experiences marital problems. The scale was translated and adapted to Portuguese by Falcke (2003), with a Cronbach's Alpha coefficient of .80. For this study, considering that it relates to romantic relationships, the question "It is useless to keep up a marriage beyond a certain point" was adapted to "It is useless to keep up a relationship beyond a certain point". In this study, the adapted version of the scale obtained a Cronbach's Alpha coefficient of .90.

Sternberg's Triangular Love Scale (STLS). Used to assess the following dimensions of love: intimacy, passion and decision/commitment. It consists of 45 items, subdivided among the three components, each of which is represented by 15 items (Sternberg, 1997). In this research, the Brazilian version of the scale was used (Cassepp-Borges \& Teodoro, 2007), with a Cronbach's Alpha coefficient superior to 90 for each of its items (intimacy $=.94$; passion $=.93$; decision $/$ commitment $=.96$ ). As the study involves relationships mediated by the Internet, the question "I strongly like physical contact with was adapted to "I strongly like contact with .. The total Cronbach's Alpha for the adapted version of the scale was .98 , with coefficients superior to .95 for the subscales (intimacy: .96; passion: .95; decision/commitment: .97).

\section{Procedure}

Data collection. Through a research link, an invitation was forwarded, in which the users were informed about the research objectives and procedures, as well as the confidentiality of the data and the anonymous nature of their cooperation.
These invitations were sent by e-mail and through messages in social networks. The questionnaire was applied through the Internet, by means of a form the researchers created.

The decision to answer the research questionnaire or not was exclusively taken by the users, who decided to be included in the sample or not by marking "Yes" or "No" when they were asked if they accepted to participate in the research, agreeing with the Informed Consent Term.

Data analysis. The data were analyzed by means of parametric statistics, using the software SPSS 20.0 (Statistical Package for Social Science 20.0). The $t$ test for independent samples was used to compare the groups of participants involved in relationships mediated by the Internet or not, and Pearson's Correlation to associate the variables under analysis. Results with $p<.05$ were considered significant.

\section{Ethical Considerations}

This research complies with the orientations of National Health Council Resolution 196/1996 (1996) and Federal Psychology Council Resolution 016/2000 (2000) about research involving human beings. Approval was obtained from the Research Ethics Committee at Universidade do Vale do Rio dos Sinos (UNISINOS) under protocol number $11 / 195$. The data were collected individually through the Internet. The identification data of all research participants, such as the IP address and the e-mail, were kept secret.

\section{Results}

The mean length of the physical romantic relationships was 11.93 months $(S D=14.39)$, and the mean length of the romantic relationships mediated by 
the Internet 8.37 months $(S D=14.27)$. Most participants who were involved in a romantic relationship mediated by the Internet declared themselves single (71.8\%), despite considering that they were involved in a romantic relationship. Moreover, $28.2 \%$ of the participants in a romantic relationship not mediated by the Internet also declared themselves single, totaling $43.8 \%$ of the research sample. Most participants (56.2\%) indicated their marital situation as having a partner $(28.2 \%$ mediated by the Internet; $82.9 \%$ not mediated by the Internet).

As observed in Figure 1, clear differences between the groups appear with regard to the quality of the relationship.

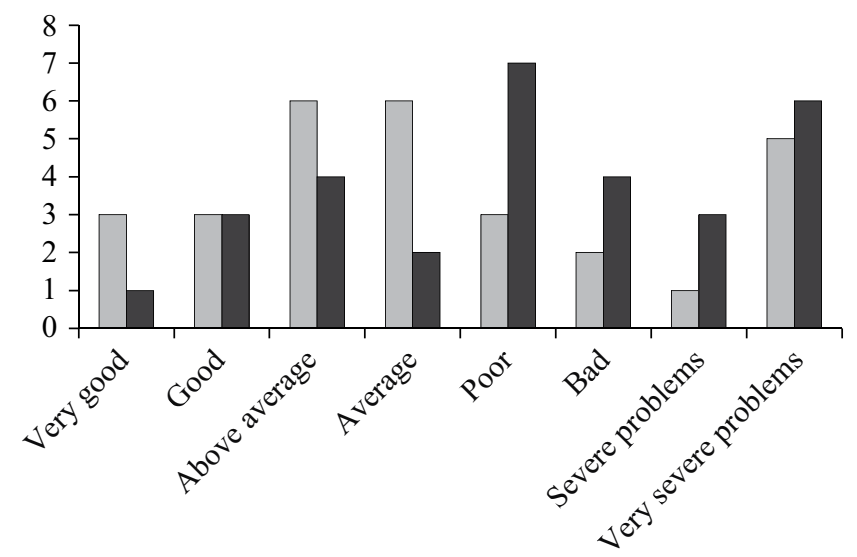

$\square$ Physical romantic relationships (PRR)

- Romantic relationship mediated by the internet (RRMI)

Figure 1. Intergroup difference with regard to marital quality.

A significant difference was found, indicating that the participants involved in a physical relationship indicated a better marital quality $(p=.05)$. This is also observed in the Table 2 .

The higher mean score on the global marital satisfaction measure, as presented earlier, indicates the presence of further marital problems in relationships mediated by the Internet. Despite a significant difference in the comparison between the quality of the romantic relationships mediated and not mediated by the Internet, however, according to the Golombok Rust Inventory of Marital State - GRIMS (Rust et al., 1988), when we inquired about the users' opinions with regard to their satisfaction with their relationship (Table 3), using a broader question ("Mark on the scale how satisfied you are with your romantic relationship"), answered on a five-point Likert scale (dissatisfied, somewhat satisfied, neither satisfied nor dissatisfied, very satisfied and totally satisfied), only trend towards greater satisfaction was verified in the physical romantic relationships ( $p=.083, t=8.231)$.

In the analysis of the components of love, it was verified that the romantic relationships mediated by the Internet obtain lower scores for intimacy $(p=.018)$ and decision/ commitment ( $p=.013)$ when compared to the physical romantic relationships. No significant intergroup differences were found with regard to passion $(p=.114)$. Nevertheless, a significant difference was found in the total Scale score $(p=.012)$, as observed in the following Table 4 .

Finally, the marital quality was correlated with the three love components and the general STLS score. The data indicate a correlation between marital quality and intimacy $(p<.001 ; r=-.679)$, passion $(p<.001 ; r=-.526)$, decision/ commitment $(p<.001 ; r=-.630)$ and with the total love score $(p<.001 ; r=-.629)$.

\section{Discussion}

The fact that almost half of the participants declared they were single (43.8\%), although the option of indicating they had a partner was available, may reflect in this study what Bauman (2004) attributes to the liquid modernity, in which the fragility of social bonds is linked to falling in love and moderating one's passion, treating relationships as a product for instantaneous consumption. In addition, according to the author, the relationships have neither depth nor durability, because the people want to avoid devastating suffering, often caused by deeper relationships. Therefore, people seek relationships through the Internet, which permit connecting and disconnecting easily.

Table 2

Global Mean Score of Marital Quality

\begin{tabular}{lccc}
\hline Type of relationship & $M$ & $S D$ & $t$ \\
\hline Not mediated by Internet & 29.45 & 11.91 & $-1.199 *$ \\
Mediated by Internet & 35.25 & 11.76 & \\
\hline
\end{tabular}

$* p<.05$.

Table 3

Users' Opinion About Satisfaction With the Relationship

\begin{tabular}{lccccc}
\hline & Dissatisfied & Somewhat satisfied & $\begin{array}{c}\text { Neither satisfied nor } \\
\text { dissatisfied }\end{array}$ & Very satisfied & Totally satisfied \\
\hline $\begin{array}{l}\text { Not mediated by } \\
\begin{array}{l}\text { Internet } \\
\text { Mediated by Internet }\end{array}\end{array}$ & $0 \%$ & $14.3 \%$ & $19.0 \%$ & $42.9 \%$ & $23.8 \%$ \\
& $2.4 \%$ & $22.0 \%$ & $31.7 \%$ & $39.0 \%$ & $4.9 \%$ \\
\hline
\end{tabular}


Table 4

Analysis of Three Love Components

\begin{tabular}{lccc}
\hline Type of relationship & $M$ & $S D$ & $t$ \\
\hline STLS Intimacy & & & $2.422^{*}$ \\
$\quad$ Not mediated by Internet & 108.86 & 25.65 & \\
$\quad$ Mediated by Internet & 93.00 & 29.53 & 1.603 \\
STLS Passion & 99.25 & 26.78 & \\
$\quad$ Not mediated by Internet & 88.80 & 27.78 & $2.556^{*}$ \\
$\quad$ Mediated by Internet & 101.21 & 29.75 & \\
STLS Decision/Commitment & 81.60 & 35.26 & $2.612^{*}$ \\
$\quad$ Not mediated by Internet & & & \\
$\quad$ Mediated by Internet & 312.06 & 82.96 & \\
STLS General & 249.60 & 94.35 & \\
$\quad$ Not mediated by Internet & & & \\
Mediated by Internet & &
\end{tabular}

$* p<.05 . * * p<.01$.

The correlations found evidence that the dimensions of love influence the marital quality and vice-versa, permitting an understanding of the interaction established among them and the need for all elements of love to be present for the relationship to be considered satisfactory. In a study by Rizzon, Mosmann and Wagner (2013) which involved 102 participants from the State of Rio Grande do Sul, in a physical relationship (married or living with a fixed partner), between 19 and 79 years of age, a positive and significant correlation was found between the marital quality measures and love, measured by means of the STLS. Mônego and Teodoro (2011) investigated 192 college students in relationships not mediated by the Internet and found a correlation between the components of love and satisfaction, revealing that the way people perceive their relationship is associated with the extent of their satisfaction with that relationship. Those results are supported by the present study, showing that what the Scale measures as love is directly associated with the partners' perception about the quality of their relationship.

As observed, in general, the romantic relationships mediated by the Internet present higher scores at the bottom levels of the marital quality scale (poor, bad, severe problems and very severe problems). Physical relations, on the other hand, show higher scores at the top levels of the scale (very good, above average and average), revealing a better marital quality, which indicates the presence of greater satisfaction, trust, communication and shared interests in the physical relationships.

The data indicate that the passion dimension is similar in the relationships mediated and not mediated by the Internet. According to Sternberg (1986), passion can emerge instantaneously, when someone feels attracted to another person at any level. As the motivational component of love corresponds to feelings of attraction, romance and sexuality (Mônego \& Teodoro, 2011), it may be present in the different modalities of romantic relationships, whether mediated by the Internet or not.

On the other hand, significant differences were observed in intimacy and decision/commitment. As regards the factors of the triangular theory of love, Cassepp-Borges and Pasquali (2012) and Sternberg (1997) describe that the factors intimacy and commitment are more stable than the factor passion. They highlight that great control is possible over the decision/commitment factor, and some control over intimacy, but very little control over passion, which has an important function in short relationships, depending on psychophysiological components. In that sense, in short relationships, the passion factor is always high, while intimacy and commitment can vary, as intimacy grows over time and decision/commitment depends on a possibly even longer time. As the mean length of physical romantic relationships (11.93 months; $S D=14.39$ ) was a bit longer when compared to the mean length of romantic relationships mediated by the Internet (8.37 months, $S D=14.27)$, one might suggest that RRMI are shorter and, therefore, that intimacy and decision/commitment may not have developed yet. Intimacy is considered common in different relationships, like between lovers, family or friends. Passion, on the other hand, is only common in romantic relationships and decision/commitment is difficult to happen in other types of relationships. Earlier studies, involving people in physical relationships, indicate decision/commitment as the preponderant element in the relationship (Cassepp-Borges \& Teodoro, 2007; Karwowski-Marques, 2008; Mônego \& Teodoro, 2011) and an essential component of a long-lasting relationship, going against the fluidness of relationships. According to Rizzon et al. (2013), at times of crisis, this element grants balance to the relationship, as it makes the couple perceive that the commitment is not transitory.

As regards intimacy, Joinson (1998) describes that, through the Internet, people establish deeper and more direct connections, and therefore end up being more uninhibited when sharing information. In that sense, the authors consider that the partners establish more intimacy through their attitudes, objectives and thoughts. McKenna, Green and Gleason (2002) support this conception, describing that the relations constituted through the Internet will develop intimacy faster when 
compared to a physical relationship because there are more solid bases, due to the self-exposure of their characteristics and shared interests. Young (2006) also reports that, due to the low level of inhibition in communication mediated by the Internet, people express their emotions more open and honestly and at a faster pace, which grants a feeling of profound intimacy. These data go against the present research findings, which in turn are in accordance with Rice and Love (1997) when they argue that romantic relationships mediated by the Internet are more impersonal and less intimate than physical relationships.

According to Sternberg (1996), more intimate couples grant more pleasure to one another and, consequently, satisfy each other more. People demonstrate their love through actions and express their intimacy by communicating their internal feelings, promoting each other's wellbeing, sharing their time, their belongings and themselves, demonstrating empathy for their partner and giving them emotional support. At the start of the relationship, the couple is unable to predict each other's actions, emotions, motivations and thoughts. In that sense, intimacy remains quite latent and increases over time, to the same extent as the mutual interactions. Then, foreseeing actions becomes possible and the couple gets to know each other better (Sternberg, 1986). In a study by Karwowski-Marques (2008), involving 50 heterosexual couples in a physical relationship, intimacy was indicated as the main construct of love that explains the variance in the level of satisfaction with the romantic relationship. In that sense, the difference in the intimacy dimension between romantic relationships mediated and not mediated by the Internet observed in this study may contribute to the reduction in the marital quality of these relationships.

As regards decision/commitment, the former frequently precedes the latter. This factor refers to the certainty to love and be loved and the desire to maintain that love in the long term. The forms of expressing commitment may be frequent on the Internet, through declarations of belonging, possession, promises and oaths. One of the justifications found for the significant difference observed in this factor, indicating that it is more present in the physical relationship group, is the fact that, in these relationships, there are factors that make the perspective of maintaining the relationship in the long term more difficult. In that sense, the Internet could be considered an important tool to meet people but, for the relationship to be developed, a perspective of a future physical meeting would be needed, so that the couple would establish a stronger commitment to the relationship bond.

In that sense, it can be inferred that the conception of consummate love, including the three components of love, is closer to physical romantic relationships than to Internetmediated ones, the latter being more characterized by infatuation, in which only passion is more clearly present.

\section{Conclusion}

The romantic relationships constituted through the Internet have been a source of public debates and scientific research. Most people involved in this type of relationship hesitate to assume their condition before friends and relatives (Rosen, Cheever, Cummings, \& Felt, 2008), as little is known about the theme. According to the present study results, the relationships mediated by the Internet predominantly involve passion, characterized by a high level of excitement, which tends to be momentary, as it does not include the other components for support.

Authors (Lemieux \& Hale, 2000) indicate that the three components of love predict satisfaction in the relationship, in accordance with the present findings, showing greater intimacy and decision/commitment in the physical romantic relationships, as well as greater marital quality. In the romantic relationships mediated by the Internet, on the other hand, it is suggested that there are more marital problems, in view of the lower marital quality scores. In that sense, it can be inferred that the Internet is an excellent tool for people to meet but, for the development of intimacy and commitment, it is important for the relationship to develop in a physical context.

Because of its exploratory, comparative and correlational design, this study revealed the differences between the mediated and physical relationships with regard to the dimensions of love and the marital quality, as well as the association between these variables. Nevertheless, further investments are needed in many other studies on this research theme, especially in the attempt to gain a deeper understanding of the dynamics of Internetmediated relationships. Hence, we suggest the development of studies with couples, considering aspects like motivation for the relationship and bonding characteristics, besides discussing how the Internet-mediated relationships develop over time.

\section{References}

Andrade, A. L., Cruz, R. M., Wachelke, J. F. R., Souza, A. M., Nicolau, M. E. B., Rodrigues, P. F. U., \& Bento, R. R. (2005, maio). Relações entre satisfação com o relacionamento amoroso, aspectos especificos da interação e bem-estar psicológico. Trabalho apresentado no Segundo Congresso Brasileiro de Avaliação Psicológica, Gramado, RS.

Arias, I., \& House, A. S. (1998). Tratamiento cognitivo conductal de los problemas de pareja. In V. E. Caballo (Dir.), Manual para el tratamiento cognitivo-conductal de los trastornos psicológicos: Vol. 2. Formulación clínica, medicina conductal y trastornos de relación (pp. 553-577). Madrid, España: Siglo XXI.

Arriaga, X. B. (2001). The ups and downs of dating: Fluctuations in satisfaction in newly formed romantic relationships. Journal of Personality and Social Psychology, 80(5), 754-765. doi:10.1037/0022-3514.80.5.754

Bauer, M. W., \& Gaskell, G. (2003). Pesquisa qualitativa com texto, imagem e som: Um manual prático (P. A. Guareschi, Trad.). Petrópolis, RJ: Vozes.

Bauman, Z. (2004). Amor líquido: Sobre a fragilidade dos laços humanos (C. A. Medeiros, Trad.). Rio de Janeiro, RJ: Zahar. 
Beall, A. E., \& Sternberg, R. J. (1995). The social construction of love. Journal of Social and Personal Relationships, 12(3), 417-438. doi:10.1177/0265407595123006

Cassepp-Borges, V., \& Pasquali, L. (2012). Estudo nacional dos atributos psicométricos da Escala Triangular do Amor de Sternberg. Paidéia (Ribeirão Preto), 22(51), 21-31. doi:10.1590/S0103-863X2012000100004

Cassepp-Borges, V., \& Teodoro, M. L. M. (2007). Propriedades psicométricas da versão brasileira da escala triangular do amor de Sternberg. Psicologia: Reflexão e Crítica, 20(3), 513-522. doi:10.1590/S0102-79722007000300020

Conselho Federal de Psicologia. (2000, 20 dezembro). Resolução No. 016/2000. Dispõe sobre a realização de pesquisa em Psicologia com seres humanos. Brasília, DF: CFP.

Conselho Nacional de Saúde. (1996, 10 de outubro). Resolução No. 196/1996. Diretrizes e normas regulamentadoras de pesquisas envolvendo seres humanos. Brasília, DF: CNS.

Civiletti, M. V. P., \& Pereira, R. (2002). Pulsações contemporâneas do desejo: Paixão e libido nas salas de batepapo virtual. Psicologia: Ciencia e Profissão, 22(1), 38-49.

Cuminale, N. (2009). Perfil dos usuários dos sites de relacionamento amoroso. Veja. Retrieved from http:// veja.abril.com.br/noticia/saude/perfil-usuarios-sitesrelacionamento

David, P., \& Stafford, L. (2013). A relational approach to religion and spirituality in marriage the role of couples: Religious, communication in marital satisfaction. Journal of Family Issues. doi:10.1177/0192513X13485922

Dela Coleta, M. F. (1989). A medida de satisfação conjugal: Adaptação de uma escala. Psico, 18(2), 90-112.

Dela Coleta, M. F. (2012). Locus de controle e satisfação conjugal. Psicologia: Teoria e Pesquisa, 8(2), 243-252.

Engel, G., Olson, K. R., \& Patrick, C. (2002). The personality of love: Fundamental motives and traits related to components of love. Personality and Individual Differences, 32(5), 839853. doi:10.1016/S0191-8869(01)00090-3

Ephron, N. (Director). (1998). You've got mail [DVD]. United States: Warner Bros.

Falcke, D., Diehl, J. A., \& Wagner, A. (2002). Satisfação conjugal na atualidade. In A. Wagner (Org.), A família em cena: Tramas, dramas e transformações (pp. 172-188). Petrópolis, RJ: Vozes.

Falcke, D. (2003). Águas passadas não movem moinhos? As experiências na família de origem como preditoras da qualidade do relacionamento conjugal (Unpublished doctoral dissertation). Universidade Federal do Rio Grande do Sul, Porto Alegre, RS.

Freire, B., Machado, D., Queiroz, F., Bezerra, L., Freire, R. S., Vasconcelos, A. J., \& Cruzy, K. (2010, setembro). Paixão, ciúme e traição: A "liquidez" das relações humanas no ciberespaço. Trabalho apresentado no Congresso Brasileiro de Ciências da Comunicação, Caxias do Sul, RS. Retrieved from http://www.intercom.org.br/papers/ nacionais/2010/resumos/R5-0733-1.pdf
Freud, S. (1969). O mal estar na civilização (J. O. A. Abreu, Trad.). Rio de Janeiro, RJ: Imago.

Gao, G. (2001). Intimacy, passion, and commitment in Chinese and US American romantic relationships. International Journal of Intercultural Relations, 25(3), 329-342 doi:10.1016/S0147-1767(01)00007-4

Haack, K. R., \& Boeckel, M. G. (2009). Relacionamento@ amoroso.com.br (Unpublished manuscript). Faculdades Integradas de Taquara, Taquara, RS.

Hand, M. M., Thomas, D., Buboltz, W. C., Deemer, E. D., \& Buyanjargal, M. (2013). Facebook and romantic relationships: Intimacy and couple satisfaction associated with online social network use. Cyberpsychology, Behavior, and Social Networking, 16, 8-13.

Hendrick, S. S.(1981). Self-disclosureandmarital satisfaction. Journal of Personality and Social Psychology, 40(6), 1150-1159. doi:10.1037/0022-3514.40.6.1150

Hernandez, J. A. E. (1999). Validação da estrutura da Escala Triangular do Amor: Análise fatorial confirmatória. Aletheia, (9), 15-26.

Hernandez,J.A.E.,\&Oliveira,I.M.B.(2003).Oscomponentes do amor e a satisfação. Psicologia: Ciência e Profissão, 23(1), 58-69. doi:10.1590/S1414-98932003000100009

Joinson, A. (1998). Causes and implications of disinhibited behavior on the Internet. In J. Gackenbach (Ed), Psychology and the Internet: Intrapersonal, interpersonal, and transpersonal implications (pp. 43-60). San Diego, CA: Academic Press.

Karwowski-Marques, A. P. M. (2008). Percepções sobre o amor, a qualidade e a satisfação com o relacionamento em casais (Unpublished master's thesis). Universidade do Vale do Rio dos Sinos, São Leopoldo, RS.

Kraut, R., Patterson, M., Lundmark, V., Kiesler, S., Mukopadhyay, T., \& Scherlis, W. (1998). Internet paradox: A social technology that reduced social involvement and psychological well-being? American Psychologist, 53(9), 1017-1031.

Lai, C.-H., Lin, C.-Y., Chen, C.-H., Gwung, H.-L., \& Li, C.-H. (2013). Can Internet usage positively or negatively affect interpersonal relationship? In R.-S. Chang, L. C. Jain, \& S.-L. Peng (Eds.), Advances in intelligent systems and applications (Vol. 1, pp. 373-382). Berlin, Germany: Springer. doi:10.1007/978-3-642-35452-6_38

Lea, M., \& Spears, R. (1995). Love at first byte? Building personal relationships over computer networks. In J. T. Wood \& S. Duck (Eds.), Under-studied relationships: Off the beaten track (pp. 197-233). Thousand Oaks, CA: Sage.

Lemieux, R., \& Hale, J. L. (2000). Intimacy, passion and commitment among married individuals: Further testing of the Triangular Theory of Love. Psychological Reports, 87 (3, Pt 1), 942-948. doi:10.2466/PR0.87.7.941-948

McKenna, K. Y. A., Green, A. S., \& Gleason, M. E. J. (2002). Relationship formation on the Internet: What's the big attraction? Journal of Social Issues, 58(1), 9-31. doi:10.1111/1540-4560.00246 
Meltzer, A. L., McNulty, J. K., Jackson, G. L., \& Karney, B. R. (2013). Sex differences in the implications of partner physical attractiveness for the trajectory of marital satisfaction. Journal of Personality and Social Psychology. doi:10.1037/a0034424

Minha vida amorosa na Internet. (2009). Época. Retrieved from http://revistaepoca.globo.com/Revista/ Epoca/0,,EMI93880-15228,00.html

Mônego, B. G., \& Teodoro, M. L. M. (2011). A teoria triangular do amor de Sternberg e o modelo dos cinco grandes fatores. Psico-USF, 16(1), 97-105. doi:10.1590/S1413-82712011000100011

Mosmann, C., Wagner, A., \& Féres-Carneiro, T. (2006). Qualidade conjugal: Mapeando conceitos. Paidéia (Ribeirão Preto), 16(35), 315-325. doi:10.1590/S0103-863X2006000300003

Mosmann, C. P., Zordan, E. P., \& Wagner, A. (2011). A qualidade conjugal como fator de proteção do ambiente familiar. In A. Wagner (Org.), Desafios psicossociais da família contemporânea: Pesquisas e reflexões (pp. 58-71). Porto Alegre, RS: Artmed.

Naar, H. (2013). A dispositional theory of love. Pacific Philosophical Quarterly, 94(3), 342-357. doi:10.1111/papq.12003

Neves, S. (2003). Amor, poder e violência(s) contra as mulheres: A importância do género nas relações íntimas. Psicologia: Teoria, Investigação e Prática, 8(1), 133-144.

Oltramari, L. C. (2009). Amor e conjugalidade na contemporaneidade: Uma revisão de literatura. Psicologia em Estudo, 14(4), 669-677. doi:10.1590/S1413-73722009000400007

Rice, R. E., \& Love, G. (1997). Electronic emotion: Socioemotional content in a computer- mediated communication network. Communication Research, 14(1), 85-108. doi:10.1177/009365087014001005

Rizzon, A. L. C., Mosmann, C. P., \& Wagner, A. (2013). A qualidade conjugal e os elementos do amor: Um estudo correlacional. Contextos Clínicos, 6(1), 41-49. doi:10.4013/ctc.2013.61.05

Rosen, L. D., Cheever, N. A., Cummings, C., \& Felt, J. (2008). The impact of emotionality and selfdisclosure on online dating versus traditional dating. Computers in Human Behavior, 24(5), 2124-2157. doi:10.1016/j.chb.2007.10.003

Rust, J., Bennun, I., Crowe, M., \& Golombok, S. (1988). The Golombok rust inventory of marital state. Windsor, England: NFER-Nelson.

Sanderson, C. A., \& Cantor, N. (1997). Creating satisfaction in steady dating relationships: The role of personal goals and situational affordances. Journal of Personality and Social Psychology, 73(6), 1424-1433. doi:10.1037/0022-3514.73.6.1424

Scherma, M., \& Marques, M. L. (2012). Amor virtual: Como lidar. TodaTeen. Retrieved from http://todateen.uol.com. br/souassimtt/amor-virtual-como-lidar/
Schopenhauer, A. (1970). Dores do mundo (A. F. Sampaio, Trad.). São Paulo, SP: Edições de Ouro.

Silva Neto, J. A., Mosmann, C. P., \& Lomando, E. (2009). Relações amorosas \& Internet. São Leopoldo, RS: Sinodal.

Slouka, M. (1995). War of the worlds: Cyberspace and the high-tech assault on reality. New York, NY: Basic Books.

Sternberg, R. J. (1986). A triangular theory of love. Psychological Review, 93(2), 119-135. doi:10.1037/0033-295X.93.2.119

Sternberg, R. J. (1989). El triangulo del amor: Intimidad, pasión y compromiso. Barcelona, España: Paidós.

Sternberg, R. J. (1996). Successful intelligence: How practical and creative intelligence determine success in life. New York, NY: Simon \& Schuster.

Sternberg, R. J. (1997). Construct of a triangular love scale. European Journal of Social Psychology, 27(3), 313-335. doi:10.1002/(SICI)1099-0992(199705)27:3<313::AIDEJSP824>3.0.CO;2-4

Sternberg, R. J. (1998). Cupid's arrow: The course of love through time. New York, NY: Cambridge University Press.

Wachelke, J. F. R., Andrade, A. L., Cruz, R. M., Faggiani, R. B., \& Natividade, J. C. (2004). Medida da satisfação em relacionamento de casal. Psico-USF, 9(1), 11-18. doi:10.1590/S1413-82712004000100003

Wagner, A., \& Falcke, D. (2001). Satisfação conjugal e transgeracionalidade: Uma revisão teórica sobre o tema. Psicologia Clínica, 13(2), 11-24.

Wesley, D. (2011). A business of love: Online dating by the numbers. Retrieved from http://www.visualeconomics. com/a-business-of-love-online-dating-by-the-numbers/

Young, K. S. (2006). Online infidelity: Evaluation and treatmentimplications.Journal ofCoupleandRelationship Therapy, 5(2), 43-56. doi:10.1300/J398v05n02_03

Karla Rafaela Haack holds a M.Sc. in Clinical Psychology from Universidade do Vale do Rio dos Sinos.

Denise Falcke is a Professor at Universidade do Vale do Rio dos Sinos.

Received: Jan. $17^{\text {th }}, 2013$

$1^{\text {st }}$ Revision: Oct. $30^{\text {th }}, 2013$

$2^{\text {nd }}$ Revision: Jan. $29^{\text {th }}, 2014$

Approved: Feb. $10^{\text {th }}, 2014$

How to cite this article:

Haack, K. R., \& Falcke, D. (2014). Love and marital quality in romantic relationships mediated and non-mediated by Internet. Paidéia (Ribeirão Preto), 24(57), 105-113. doi:10.1590/1982-43272457201413 


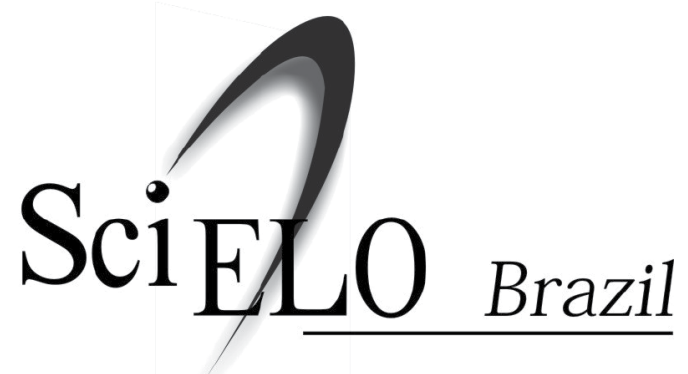

Paidéia (Ribeirão Preto) is a four-monthly publication available in full-text in the Scientific Electronic Library Online - SciELO.

The SciELO interface provides easy access to the tables of content and to the full-text articles.

The SciELO interface also provides the retrieval of articles by the author's name, the words from title, abstract and descriptors, in addition to providing bibliometric indicators and consultation indicators.

The articles are enriched with connections to the LILACS, MEDLINE and PubMed databases.

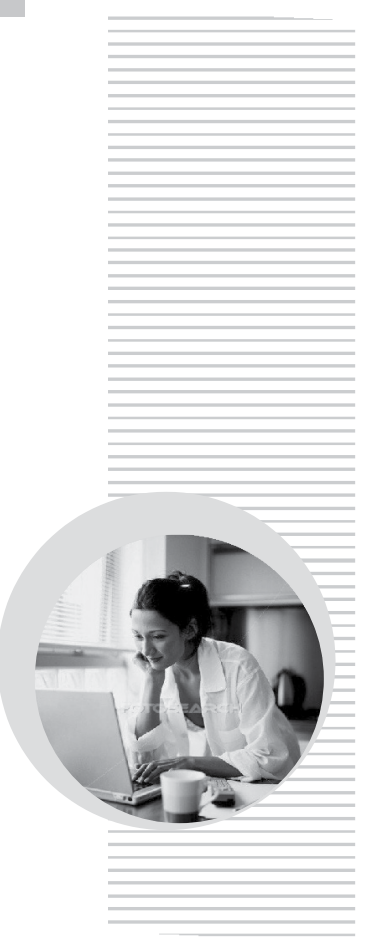

Paidéia (Ribeirão Preto) is a part of SciELO Brazil:

\section{www.scielo.br/paideia}

The SciELO interface provides access to a network of SciELO websites, gathering the major scientific journals of Latin America, Caribbean, Spain, Portugal and South Africa:

\section{www.scielo.org}

The electronic library is a project developed by the São Paulo Research Foundation (FAPESP), in partnership with the Latin American and Caribbean Center on Health Sciences Information (BIREME) and the National Council for Scientific and Technological Development (CNPq). 